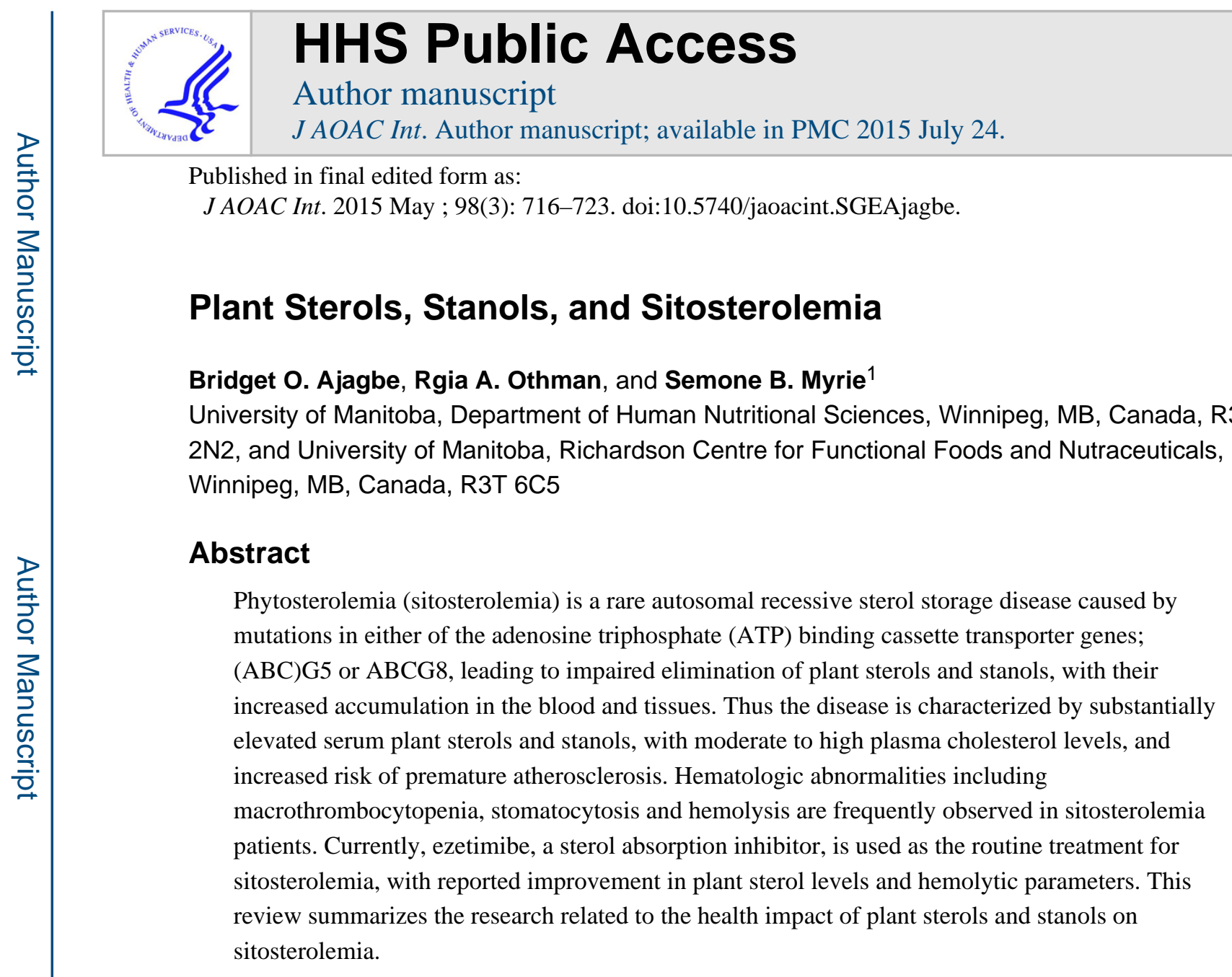

Sitosterolemia, also known as phytosterolemia (OMIM 210250), is a rare autosomal recessive sterol storage disorder caused by homozygous or compound heterozygous mutations in one of the two adenosine triphosphate binding cassette (ABC) genes, $A B C G 5$ and $A B C G 8$, located on human chromosome $2 \mathrm{p} 21$ (1-3). These genes encode the heterodimer transporter ABCG5/G8, which is expressed in enterocytes, in the proximal small intestine, and hepatocytes $(4,5)$, and function to rapidly excrete cholesterol, plant sterols (PS) and their saturated derivatives (stanols) from the body. The ABCG5/G8 transporters work to limit intestinal uptake of these sterols, promoting their biliary secretion, and subsequently preventing their accumulation in the body (5-8). Sitosterolemia is characterized by significant elevation of serum PS and stanols (2, 9-11) with potential PS build-up in the arteries, skin (xanthomas), and tissues (12). Total cholesterol level can be normal to moderately in some sitosterolemia patients (7) although in some cases it can be extremely high (13). Individuals with sitosterolemia may present with tendon xanthomas and in some cases the tendency to develop coronary disease at an early age $(10,14,15)$.

Several cases of hematological abnormalities have been observed in sitosterolemia patients (16-18). High plasma PS levels have been shown to have pernicious effects on platelet formation (e.g., reduced platelet count and increased platelet size and subsequently increased bleeding) in ABCG5 deficient mice (19-21). Severe bleeding episodes, resulting

${ }^{1}$ Corresponding author's Semone.myrie@umanitoba.ca. 
from macrothrombocytopenia, have been reported in sitosterolemia patients, along with other hematologic abnormalities including hemolytic anemia with stomatocytes or deformed red blood cells (22-25). In agreement with the findings of others (22), we have recently shown that treatment of sitosterolemia patients with ezetimibe, a sterol absorption inhibitor, lowered PS levels and improved platelet count and size (26). The main objective of this work is to review the effects of PS and stanols on the health of individuals with sitosterolemia, including the impact on cardiovascular disease risk, hematologic variables, and other potential emerging issues associated with the disease.

\section{Pathophysiology of Sitosterolemia}

Xanthomas (tendon and tuberous), premature atherosclerosis, hematological abnormalities (e.g., chronic hemolytic anemia, and thrombocytopenia), and arthritis are common clinical features of sitosterolemia $(2,10,14,15)$. Endocrine disruption has only been reported once in a case from Bangladesh (27). Individuals with homozygous sitosterolemia have increased amounts of PS, including sitosterol and campesterol in blood, and various tissues, especially in xanthomas and arteries (28). Premature atherosclerosis has been reported in some patients $(29,30)$, although it has been argued that premature atherosclerosis is not systematic in sitosterolemia (31).

Hematologic abnormalities including macrothrombocytopenia, stomatocytosis, and hemolysis are frequently observed in sitosterolemia patients, and in some recent reports this may be the first indication that the person may have the disorder (32-34). Rees et al. reported Mediterranean macrothrombocytopenia in 10 sitosterolemia patients, originally from the Mediterranean, residing in Australia (22). Su et al. reported on three Chinese sitosterolemia patients, who at age 3 or 4 years had evidence of hemolysis with reticulocytosis; increased immature red blood cell, with low hemoglobin levels (2.7-5.0 g/ dl), and splenomegaly. Splenectomies at 13 or 14 years of age markedly improved anemia in these patients (32).

\section{Metabolism of Plant Sterols and Stanols in Sitosterolemia}

In 1998, the sitosterolemia gene was mapped to chromosome 2 p21 (1), and candidate gene analysis excluded lipid metabolic-related genes such as 3-hydroxyl-methyl-glutaryl-CoA (HMG-CoA) reductase, HMG-CoA synthase, LDL-receptor, sterol regulatory element binding proteins (SREBP)-1, and -2, acyl coenzyme A:cholesterol acyltransferase and microsomal triglyceride transfer protein as the cause of the disease (35). Rather, sitosterolemia was due to a mutation in one of the two adjacent and highly homologous ABC genes, ABCG5 or ABCG8 $(36,37)$, which are involved in the intestinal absorption of sterols and their excretion in bile $(1,5)$. The ABCG5 and ABCG8 proteins (Sterolin-1 and Sterolin-2) form a heterodimer transporter in the endoplasmic reticulum in enterocytes and hepatocytes $(38,39)$. These transporters are located in the brush border membrane of enterocytes and the canalicular membrane of hepatocytes, where it mediates the transport of absorbed sterol from the intracellular to the extracellular space.

Plant sterols and cholesterol are absorbed by the same mechanism, however, in a normal healthy individual the former are assimilated at lower rates than cholesterol (40). Hence, the 
average dietary intake of PS has been estimated between $400 \mathrm{mg}$ /day in normal individuals (41), of which less than 5\% is absorbed. Conversely, about $15-60 \%$ of the consumed PS is absorbed in homozygous sitosterolemia patients $(2,8,30,31)$. The significantly increased PS absorption in sitosterolemia occurs via a complex process involving the uptake of dietary cholesterol and PS into the micellar compartment and transfer into enterocytes. Thus, mutation in the ABCG5/G8 heterodimer transporter affects the intestinal cholesterol and PS excretion from enterocytes into the intestinal lumen, and from hepatocytes into the bile. As a result, PS accumulate in the blood $(11,34)$ and tissues instead of being secreted back into the intestinal lumen and bile (42-45; Figure 1).

Normally dietary PS are incorporated into micelles in the small intestine and secreted into circulation through chylomicrons while competing for space in mixed micelles, thereby reducing cholesterol uptake by the enterocytes as micelles move from the intestinal lumen to the brush border $(46,47)$. The micelles are partially absorbed into the intestinal lumen via the sterol absorption transporter; Niemann-Pick C1 Like 1 (NPC1L1), located in intestinal brush border membrane (48), and transported into enterocytes as free cholesterol. In the enterocyte, the majority of the absorbed cholesterol is esterified by acylcholesterol acyl transferase (ACAT2); a key enzyme in cellular cholesterol metabolism, packaged into chylomicrons within the enterocytes and transported into the circulation (49). Unesterified cholesterol and other sterols are secreted back to the intestinal by ABCG5/8 transporters at the hepatobiliary interface (Figure 2). ACAT2 is exclusively expressed in hepatocytes and enterocytes, and may help with sorting of dietary sterols in the enterocytes by differentiating among them as substrate candidates. PS are poor substrates of ACAT2 compared with cholesterol (50), which allows ABCG5/8 transporters to move these sterols out of the enterocytes into the intestinal lumen. The ABCG5/G8 transporter is also expressed in hepatocytes where it aids the excretion of PS via the biliary system (Figure 2). It is believed that free PS may be mobilized via ATP-binding cassette transporter A1 located at the basolateral membrane of enterocytes and become a part of apolipoprotein A-I, containing high-density lipoprotein (HDL) particles. In HDL, PS are esterified by lecithin:cholesterol acyltransferase almost as efficiently as cholesterol and can also be taken up from HDL in a comparable manner to that of cholesterol ester (44).

In addition to PS, 5a-stanols; PS corresponding 5a-saturated derivatives, are also present in high levels in sitosterolemia patients (51-53). Markedly elevated plasma levels of cholestanol, 5a-campestanol and 5a-sitostanol comprised the major constituents of the 5astanol profile found in individuals with sitosterolemia $(51,52)$. However, unlike PS, the majority of plasma stanols in sitosterolemia patients are derived from endogenous synthesis within the body from their unsaturated precursors $(51,52)$. Studies have shown that cholestanol is synthesized from cholesterol animals and humans $(54,55)$. Furthermore, studies have shown that exogenous PS may not be the primary precursor for the production of 5a-stanols in vivo in sitosterolemia. Skrede et al (56), found that 5a-stanols formed slowly from sitosterol, as measured via 7a-hydroxysitosterol as a precursor, but more readily from 24-ethylo-cholesen-3-one (56). 


\section{Plasma Plant Sterols, Stanols, and Risk of Cardiovascular Diseases in Sitosterolemia}

Accumulation of plasma PS and/or stanols in individuals with sitosterolemia has been linked with premature atherosclerotic plaque formation and early death (29, 52, 57-59). Elevated PS and stanols have been associated with increased risk of cardiovascular diseases (CVD) in sitosterolemia patients, as shown in the case of a 19 years old Japanese man who was diagnosed to suffer from an acute myocardial infarction, presented with xanthomas on both elbows and thickening of Achilles tendons; his total cholesterol was $310 \mathrm{mg} / \mathrm{dl}$, low-density lipoprotein (LDL)-cholesterol was $243 \mathrm{mg} / \mathrm{dl}$, and his sitosterol level was $98.6 \mathrm{mg} / \mathrm{dl}$ (60). Furthermore, Webb et al (30) recently reported a case of 16 year old Amish boy with a long familial history of coronary events and hypertension, whose lipid profile revealed an elevated total cholesterol level of $353 \mathrm{mg} / \mathrm{dl}$, and LDL-cholesterol $291 \mathrm{mg} / \mathrm{dl}$ with a $5.6 \%$ sitosterol above healthy human sitosterol levels ( $<1 \mathrm{mg} / \mathrm{dl})$. Similarly, a post-mortem report of a 5-year old girl who was homozygous mutation for ABCG8 (S107X) revealed that the patient had aortic xanthomas, marked atheromatous narrowing of the coronary and pulmonary arteries as well as a confirmed high concentration of plasma cholesterol and sitosterolemia.

Some research findings have contested the contribution of PS to increased risk of CVD sitosterolemia, while some researchers have found that high plasma PS levels do not have a positive relationship with CVD risk, but rather it may be protective $(31,57,61)$. Although it has been speculated that PS may be atherogenic and may advance atherosclerosis in nonsitosterolemic individuals $(31,61,62)$. Wilund et al (61) opined that although high plasma sitosterol levels were observed in human and mouse model of sitosterolemia there was no confirmation that high levels of plasma PS caused increased risk of coronary heart disease (CHD) in these subjects. Kurano et al. also shared a similar view based on their work with mouse macrophage cell lines, where incubation with sitosterol and campesterol at 8,16 or $160 \mu \mathrm{M}$ resulted in significantly reduced increases in the secretions of inflammatory markers (tumor necrosis factor alpha, Interleukin 6) compared to incubation with similar amounts of cholesterol (62). Thus far, the data argue in favor of amelioration effects of PS on inflammatory process and hypercholesterolemia with no evidence of a relationship between circulating levels of PS and risk of CVD found in healthy people (63). PS intake has been shown to be safe and effective in reducing circulating LDL-cholesterol levels in the general population. We previously reported that PS supplements efficiently reduced LDLcholesterol levels in heterozygous carriers of sitosterolemia, and were not associated with major elevations in serum PS that were different from the general population (64).

\section{Trends in Sitosterolemia and Other Risk Factors}

In 1974, the first report of sitosterolemia was documented in the United States in two Amish sisters who presented with elevated plasma PS level and tendon xanthomas (2). Since this first report the disease has been documented in several countries or regions, including Japan, China, Canada, and Europe (18, 24, 29, 65, 66). In 2013, Merkens et al. identified about 85 cases of sitosterolemia in the literature (67), and in 2014 at least another 23 cases have been reported $(13,24,31,68-70)$. Thus, the total known cases worldwide remain low, but this 
may in part be due to misdiagnosis as hypercholesterolemia $(13,71)$. We continue to learn more about the disorder with each new reported presentation in the development of the disease mutations, clinical features and treatment approaches. Several cases of sitosterolemia have emerged with new mutations, clinical features and other related health issues. Researchers have also employed various therapeutic measures to help lower PS levels among these individuals of different pedigrees. Trends in the progression and prevalence of the disease among individuals from diverse pedigrees over the years have been highlighted in this review. Increased PS intakes have been speculated in the development of many risk factors associated with sitosterolemia. Aside from the basic presentation of xanthomas and premature atherosclerosis in sitosterolemic patients $(18,65$, 72), new clinical features such as macrothrombocytopenia (giant platelets with reduced count), hemolytic anemia, splenomegaly and arthritis have been associated with this rare disease $(24,33,68$; Table 1$)$.

A recent rodent model suggests that defective ABCG5/G8 transporter may also be associated with reproductive function (73). Sanders and colleagues found that the expression of ABCG5/G8 transporter in the small intestine tends to be higher in female compared to male rats (73), and investigation using ABCG5/G8 sterolin-deficient mice supported that an accumulation of dietary PS have been implicated to cause reduced fertility in male rats while leading to infertility in female rats (73). The study found that PS accumulated in ovaries and adrenal glands where they control production of steroid hormones including female sex hormones (73). In addition, PS has been reported to decrease serum estrogen levels in animals and disturb estrogen metabolism, which suggests an indication for reduced fertility $(74,75)$. PS are proposed to be responsible for modifying fat storage and fertility in ABCG5/G8 knockout mice via disruption of endocrine systems and mammalian physiology; although this claim has not been demonstrated in human subjects $(76,77)$. Research has shown that exclusion of PS from the diet and blocking dietary sterol absorption with ezetimibe treatment reversed infertility in ABCG5/G8 knockout mice (77). In humans endocrine disruption has only been reported once (27), and infertility has never been reported. In fact, Mannucci et al. (78) reported a proband that was homozygous for a singlenucleotide mutation in the ABCG5 gene and later found that her mother and brother were homozygous for the same mutation. This may suggest that sitosterolemia patients are able to have children who can also be affected.

\section{Therapeutic Approaches in Treatment of Sitosterolemia}

The primary aim of therapy in sitosterolemic patients is to substantially lower plasma PS levels. Treatment strategies for sitosterolemia include dietary restriction of intake of both animal and plant based sterols, use of bile-acid sequestrants, ileal bypass surgery and sterol absorption inhibitors. Dietary restriction of cholesterol and PS (vegetable oils, margarine, nuts, seeds, avocado, and chocolate and shellfish) is one of the main recommendations given to individuals with sitosterolemia (79). However, there have been mixed results associated with low sterol diet therapy as the sole strategy for treatment of sitosterolemia. Parson and colleagues (80) reported effective lowering of plasma PS levels with low sterol diet. However, other reports $(81,82)$ have shown that diet therapy remains difficult to comply with due to poor palatability, so it is often unsuccessful in lowering plasma PS levels. 
Bile acid binding sequestrants act by binding to bile acids in the intestinal lumen and promoting its excretion in the feces; thus interrupting the enterohepatic circulation of bile acids, resulting in an increased conversion of cholesterol and other sterols into bile in the liver. Overall, this will decrease sterol levels in hepatocytes, eventually increasing their clearance from circulation. Cholestyramine, a bile acid sequestrant, treatment in combination with low PS diet has been shown to be effective in reducing plasma cholesterol and PS levels in sitosterolemia patients. Studies have shown that dosage of 8 to $15 \mathrm{~g}$ cholestyramine/day can result in 40 to $60 \%$ reduction in plasma PS levels in sitosterolemia patients $(16,52,80,82-85)$. However, not all sitosterolemic patients respond in a similar manner to cholestyramine treatment $(79,86,87)$. For instance, while administration of cholestyramine at $1 \mathrm{~g} 4 \mathrm{x}$ daily over a 1 month period to children initially led to decreased in plasma cholesterol, however, there were issues of poor compliance as well as a gradual increase in total cholesterol (86). A 9 year old who was treated with probucol, cholestryramine and colestimide decreased her serum total cholesterol level to a normal range $(172 \mathrm{mg} / \mathrm{dl})$, however, serum sitosterol levels remained very high (79). Overall, there are issues of compliance with cholestyramine, especially in studies with children, where there have been reports of inconvenient administration (unpleasant texture of cholestyramine) and gastrointestinal adverse effects, including abdominal bloating and loss of appetite, as well as suggestion of interference with uptake of fat-soluble vitamins (89). In general, there are challenges related to tolerability of optimal dosages $(79,86)$ because cholestyramine is usually prescribed as a powder with a gritty taste and therefore treatment has low compliance $(86,88)$.

Partial ileal bypass surgery (i.e., shortening of the ileum) was originally introduced as a management strategy for hypercholesterolemia as it increases intestinal bile acid loss (89). It is believed that the majority of cholesterol absorption and bile acid reabsorption occur in the distal part of the ileum. Thus, the surgery involves bypassing the last 2 meters of the small intestine; from the ileocecal junction. Partial ileal bypass surgery in sitosterolemia patients have resulted in at least 50\% reduction of plasma and cellular sterol and stanol levels (90, 91).

Currently, ezetimibe, an inhibitor of sterol absorption in intestine, has become the mainstay therapy for sitosterolemia patients $(92,93)$. Ezetimibe acts by inhibiting the absorption of dietary and biliary cholesterol and PS by blocking Niemann-Pick-C1-like 1 (NPC1L1) protein transporter, subsequently reducing the delivery of intestinal sterols to the liver, resulting in lower plasma sterol concentrations in sitosterolemia patients $(26,79,86,92)$. The efficacy of ezetimibe has been examined in various clinical studies using $10 \mathrm{mg}$ ezetimibe, alone or in combination with bile-acid sequestrants and/or statin (4 g/day) therapy, with results showing at least $25 \%$ to $27 \%$ decrease in plasma sitosterol and campesterol levels, respectively $(86,94)$. A multi-center study examined the effect of ezetimibe on reducing PS levels in 37 sitosterolemia patients (95). Patients were randomized to ezetimibe $(n=30)$ or placebo $(n=7)$ at $10 \mathrm{mg} /$ day for 8 weeks and showed significant reduction in plasma sitosterol and campesterol levels with ezetimibe (21\% and $24 \%$ vs. $4 \%$ and $3.2 \%$ increase with placebo). There were also reductions in total sterol and apolipoprotein B levels. Results from a 2-year, open-label extension study revealed 
progressive improvements in plasma sitosterol and campesterol levels with continued treatment with $10 \mathrm{mg} /$ day ezetimibe (44\% and 51\%); however, plasma PS concentrations did not further decrease after approximately 6 months of treatment and remained substantially above the normal range (94). A follow-up study assessing the effect of 40 $\mathrm{mg} /$ day of ezetimibe for 26 weeks in 27 sitosterolemia patients showed that this dosage did not produce further reductions in sitosterol beyond those observed with $10 \mathrm{mg} / \mathrm{day}$ of ezetimibe (96). Studies in children (younger than 10 year old) show that administration of ezetimibe ( $10 \mathrm{mg} /$ day), as the sole therapy, takes 3 to 4 months to significantly lower cholesterol levels in sitosterolemia patients (86), in contrast to the quicker response of 2-8 weeks in adults with sitosterolemia (95). One suggested explanation is that an immature glucuronidation system of infants limits the effectiveness of ezetimibe (86). Furthermore, although ezetimibe treatment (10 $\mathrm{mg} /$ day) in children (younger than 10 year old) did lower total cholesterol levels to near normal range and xanthomas disappeared gradually, PS levels remained elevated after extended treatment periods (6 months to 3 years; 86). A combination of ezetimibe $(10 \mathrm{mg})$ and cholestyramine $(2 \mathrm{mg})$ administered for 1 year to an 11 year old patient with sitosterolemia has been shown to decrease plasma PS levels by $50 \%$ (92). Overall, the use of ezetimibe is not well described in children. In terms of adverse effects, to date, ezetimibe has shown advantageous over other available treatment options (e.g., bile acid sequestrants). In the 2-year study by Lütjohann and colleagues, involving 30 sitosterolemia patients, the investigators found that $10 \mathrm{mg} /$ day ezetimibe was generally welltolerated throughout the 2 year study period (94). Some patients from the study reported adverse events including upper respiratory infection (25\% of patients), dizziness (14\%), headache (14\%) and abdominal pain (11\%) (94). A $40 \mathrm{mg} /$ day ezetimibe dose for 26 weeks was found to have a similar safety and tolerability profile to $10 \mathrm{mg} /$ day ezetimibe (96).

\section{Conclusion}

Based on available data, a relationship has been established between increased plasma PS concentration and risk of CVD in sitosterolemia patients. Available human and animal studies have shown diverse effects of high PS on hemolytic abnormalities, xanthomas, and promotion of premature atherosclerosis. PS have been proven to help lower LDL-cholesterol levels in the general population. However, extremely elevated plasma PS levels in sitosterolemia have been associated with increased risk of premature atherosclerosis. Treatment of sitosterolemia includes the use of bile acid sequestrants, ileal bypass surgery and ezetimibe. Moreover, studies have examined emerging issues in individuals with ABCG5/G8 mutations and the association between PS and other health risks such as tumor formation, arthritis and infertility in sitosterolemia, though this data needs further confirmation. Few reports have opposed whether PS are a risk factor for CVD in sitosterolemia. Further studies should be done on the significance of PS in other related health issues; and also in developing effective therapeutic approaches that can help to further reduce PS concentration and the risk of CVD in sitosterolemia. 


\section{References}

1. Patel SB, Salen G, Hidaka H, Kwiterovich PO, Stalenhoef AF, Miettinen TA, Grundy SM, Lee MH, Rubenstein JS, Polymeropoulos MH, Brownstein MJ. J Clin Invest. 1998; 102:1041-1044. http:// dx.doi.org/10.1172/JCI3963. [PubMed: 9727073]

2. Bhattacharyya AK, Connor WE. J Clin Invest. 1974; 53:1033-1043. http://dx.doi.org/10.1172/ JCI107640. [PubMed: 4360855]

3. Shulman RS, Bhattacharyya AK, Connor WE, Fredrickson DS. New Engl J Med. 1976; 294:482483. http://dx.doi.org/10.1056/NEJM197602262940907. [PubMed: 1246333]

4. Berge KE, Tian H, Graf GA, Yu L, Grishin NV, Schultz J, Kwiterovich P, Shan B, Barnes R, Hobbs HH. Science. 2000; 290:1771-1775. http://dx.doi.org/10.1126/science.290.5497.1771. [PubMed: 11099417]

5. Wang J, Mitsche MA, Luetjohann D, Cohen JC, Xie XS, Hobbs HH. J Lipid Res. 2014

6. Klett EL, Patel S. Curr Opin Lipidol. 2003; 14:341-345. http://dx.doi.org/ 10.1097/00041433-200308000-00001. [PubMed: 12865730]

7. Salen G, Shefer S, Nguyen L, Ness GC, Tint GS, Shore V. J Lipid Res. 1992; 33:945-957. [PubMed: 1431587]

8. Lee MH, Lu K, Patel SB. Curr Opin Lipidol. 2001; 12:141-149. http://dx.doi.org/ 10.1097/00041433-200104000-00007. [PubMed: 11264985]

9. Rao MKG, Perkins EG, Connor WE, Bhattacharyya AK. Lipids. 1975; 10:566-568. http:// dx.doi.org/10.1007/BF02532363. [PubMed: 1177671]

10. Berge KE. Ann Med. 2003; 35:502-511. http://dx.doi.org/10.1080/07853890310014588. [PubMed: 14649332]

11. Salen G, Tint GS, Shefer S, Shore V, Nguyen L. Arterioscler Thromb. 1992; 12:563-568. http:// dx.doi.org/10.1161/01.ATV.12.5.563. [PubMed: 1576118]

12. Lee MH, Lu K, Hazard S, Yu H, Shulenin S, Hidaka H, Kojima H, Allikmets R, Sakuma N, Pegoraro R, Srivastava AK, Salen G, Dean M, Patel SB. Nat Genet. 2001; 27:79-83. http:// dx.doi.org/10.1038/87170. [PubMed: 11138003]

13. Park JH, Chung IH, Kim DH, Choi MH, Garg A, Yoo EG. J Clin Endocrin Metab. 2014; 99:15121518. http://dx.doi.org/10.1210/jc.2013-3274.

14. Salen G, Patel S, Batta AK. Cardiovasc Drug Rev. 2002; 20:255-270. http://dx.doi.org/10.1111/j. 1527-3466.2002.tb00096.x. [PubMed: 12481199]

15. Sudhop T, von Bergmann K. Z Kardiol. 2004; 93:921-928. http://dx.doi.org/10.1007/ s00392-004-0165-2. [PubMed: 15599566]

16. Belamarich PF, Deckelbaum RJ, Starc TJ, Dobrin BE, Tint GS, Salen G. Pediatrics. 1990; 86:977981. [PubMed: 2251034]

17. Patel MD, Thompson PD. Atherosclerosis. 2006; 186:12-19. http://dx.doi.org/10.1016/ j.atherosclerosis.2005.10.026. [PubMed: 16325823]

18. Togo M, Hashimoto Y, Iso ON, Kurano M, Hara M, Kadowaki T, Koike K, Tsukamoto K. Clin Chim Acta. 2009; 401:165-169. http://dx.doi.org/10.1016/j.cca.2008.10.026. [PubMed: 19111681]

19. Chase TH, Lyons BL, Bronson RT, Foreman O, Donahue LR, Burzenski LM, Gott B, Lane P, Harris B, Ceglarek U, Thiery J, Wittenburg H, Thon JN, Italiano JE Jr, Johnson KR, Shultz LD. Blood. 2010; 115:1267-1276. http://dx.doi.org/10.1182/blood-2009-05-219808. [PubMed: 19846887]

20. Kanaji T, Kanaji S, Montgomery RR, Patel SB, Newman PJ. Blood. 2013; 122:2732-2742. http:// dx.doi.org/10.1182/blood-2013-06-510461. [PubMed: 23926302]

21. Kruit JK, Drayer AL, Bloks VW, Blom N, Olthof SG, Sauer PJJ, De Haan G, Kema IP, Vellenga E, Kuipers F. J Biol Chem. 2008; 283:6281-6287. http://dx.doi.org/10.1074/jbc.M706689200. [PubMed: 18156627]

22. Rees DC, Iolascon A, Carella M, O’Marcaigh AS, Kendra JR, Jowitt SN, Wales JK, Vora A, Makris M, Manning N, Nicolaou A, Fisher J, Mann A, Machin SJ, Clayton PT, Gasparini P, 
Stewart GW. Brit J Haematol. 2005; 130:297-309. http://dx.doi.org/10.1111/j.

1365-2141.2005.05599.x. [PubMed: 16029460]

23. Neff AT. Blood. 2012; 120:4283. http://dx.doi.org/10.1182/blood-2012-06-429449. [PubMed: 23310983]

24. Wang Z, Cao L, Su Y, Wang G, Wang R, Yu Z, Bai X, Ruan C. Amer J Hematol. 2014; 89:320_ 324. http://dx.doi.org/10.1002/ajh.23619. [PubMed: 24166850]

25. Wang G, Cao L, Wang Z, Jiang M, Sun X, Bai X, Ruan C. Clin Appl Thromb-Hem. 2012; 18:582587.

26. Othman RA, Myrie SB, Mymin D, Merkens LS, Roullet JB, Steiner RD, Jones PJ. J Pediatr. 2015; 166:125-131. http://dx.doi.org/10.1016/j.jpeds.2014.08.069. [PubMed: 25444527]

27. Mushtaq T, Wales JK, Wright NP. European J Endocrin. 2007; 157(Suppl 1):S61-65. http:// dx.doi.org/10.1530/EJE-07-0222.

28. Lutjohann D, Bjorkhem I, Beil UF, von Bergmann K. J Lipid Res. 1995; 36:1763-1773. [PubMed: 7595097]

29. Mymin D, Wang J, Frohlich J, Hegele RA. Circulation. 2003; 107:791. http://dx.doi.org/ 10.1161/01.CIR.0000050545.21826.AD. [PubMed: 12578886]

30. Webb TN, Ramratnam M, Evans RW, Orchard T, Pacella J, Erkan E. Pediatr Nephrol. 2014; 29:1457-1460. http://dx.doi.org/10.1007/s00467-014-2774-y. [PubMed: 24531663]

31. Hansel B, Carrie A, Brun-Druc N, Leclert G, Chantepie S, Coiffard AS, Kahn JF, Chapman MJ, Bruckert E. Atherosclerosis. 2014; 234:162-168. http://dx.doi.org/10.1016/j.atherosclerosis. 2014.02.030. [PubMed: 24657386]

32. Su Y, Wang Z, Yang H, Cao L, Liu F, Bai X, Ruan C. Haematologica. 2006; 91:1392-1395. [PubMed: 17018391]

33. Kaya Z, Niu DM, Yorulmaz A, Tekin A, Gürsel T. Pediatr Blood Cancer. 2014; 61:1457-1459. http://dx.doi.org/10.1002/pbc.24934. [PubMed: 24623560]

34. Wang GF, Wang ZY, Cao LJ, Jiang MH, Sun XH, Bai X, Ruan CG. Zhonghua Xueyexue Zazhi. 2011; 32:331-336. [PubMed: 21729603]

35. Patel SB, Honda A, Salen G. J Lipid Res. 1998; 39:1055-1061. [PubMed: 9610773]

36. Lu K, Lee MH, Hazard S, Brooks-Wilson A, Hidaka H, Kojima H, Ose L, Stalenhoef AFH, Mietinnen T, Bjorkhem I, Bruckert E, Pandya A, Brewer HB, Salen G, Dean M, Srivastava A, Patel SB. Amer J Hum Genet. 2001; 69:278-290. http://dx.doi.org/10.1086/321294. [PubMed: 11452359]

37. Berge KE, Tian H, Graf GA, Yu L, Grishin NV, Schultz J, Kwiterovich P, Shan B, Barnes R, Hobbs HH. Science. 2000; 290:1771-1775. http://dx.doi.org/10.1126/science.290.5497.1771. [PubMed: 11099417]

38. Graf GA, Yu L, Li WP, Gerard R, Tuma PL, Cohen JC, Hobbs HH. J Biol Chem. 2003; 278:48275-48282. http://dx.doi.org/10.1074/jbc.M310223200. [PubMed: 14504269]

39. Graf GA, Wei-Ping L, Gerard RD, Gelissen I, White A, Cohen JC, Hobbs HH. J Clin Invest. 2002; 110:659-669. http://dx.doi.org/10.1172/JCI0216000. [PubMed: 12208867]

40. Lammert F, Wang DQ. Gastroenterology. 2005; 129:718-734. http://dx.doi.org/10.1016/j.gastro. 2004.11.017. [PubMed: 16083725]

41. Weingärtner O, Böhm M, Laufs U. Eur Heart J. 2009; 30:404-409. http://dx.doi.org/10.1093/ eurheartj/ehn580. [PubMed: 19158117]

42. Heinemann T, Axtmann G, Von Bergmann K. Eur J Clin Invest. 1993; 23:827-831. http:// dx.doi.org/10.1111/j.1365-2362.1993.tb00737.x. [PubMed: 8143759]

43. Sehayek E. J Lipid Res. 2003; 44:2030-2038. http://dx.doi.org/10.1194/jlr.R300008-JLR200. [PubMed: 12897193]

44. Othman RA, Myrie SB, Jones PJ. Atherosclerosis. 2013; 231:291-299. http://dx.doi.org/10.1016/ j.atherosclerosis.2013.09.038. [PubMed: 24267242]

45. Yu XH, Qian K, Jiang N, Zheng XL, Cayabyab FS, Tang CK. Clin Chim Acta. 2014; 428:82-88. http://dx.doi.org/10.1016/j.cca.2013.11.010. [PubMed: 24252657]

46. Trautwein EA, Guus DSMJE, Lin Y, Mel'nikov SM, Molhuizen HO, Ntamios FY. Eur J Lipid Sci Technol. 2003; 105:171-185. http://dx.doi.org/10.1002/ejlt.200390033. 
47. Igel M, Giesa U, Lütjohann D, Von Bergmann K. J Lipid Res. 2003; 44:533-538. http://dx.doi.org/ 10.1194/jlr.M200393-JLR200. [PubMed: 12562824]

48. Altmann SW, Davis HR Jr, Zhu LJ, Yao X, Hoos LM, Tetzloff G, Iyer SPN, Maguire M, Golovko A, Zeng M, Wang L, Murgolo N, Graziano MP. Science. 2004; 303:1201-1204. http://dx.doi.org/ 10.1126/science.1093131. [PubMed: 14976318]

49. Quílez J. Clin Nutr. 2003; 22:343-351. http://dx.doi.org/10.1016/S0261-5614(03)00060-8. [PubMed: 12880600]

50. Temel RE, Gebre AK, Parks JS, Rudel LL. J Biol Chem. 2003; 278:47594-47601. http:// dx.doi.org/10.1074/jbc.M308235200. [PubMed: 12975367]

51. Dayal B, Tint GS, Batta AK, Speck J, Khachadurian AK, Shefer S, Salen G. Steroids. 1982; 40:233-243. http://dx.doi.org/10.1016/0039-128X(82)90036-8. [PubMed: 6297129]

52. Salen G, Kwiterovich PO Jr, Shefer S, Tint GS, Horak I, Shore V, Dayal B, Horak E. J Lipid Res. 1985; 26:203-209. [PubMed: 3989379]

53. Salen G, Xu G, Tint GS, Batta AK, Shefer S. J Lipid Res. 2000; 41:1883-1889. [PubMed: 11060358]

54. Salen G, Shefer S, Tint GS. Gastroenterology. 1984; 87:276-283. [PubMed: 6735073]

55. Buchmann MS, Bjorkhem I, Fausa O, Skrede S. Scand J Gastroenterol. 1985; 20:1262-1266. http://dx.doi.org/10.3109/00365528509089287. [PubMed: 3868019]

56. Skrede B, Bjorkhem I, Bergesen O, Kayden HJ, Skrede S. Biochim Biophys Acta. 1985; 836:368375. http://dx.doi.org/10.1016/0005-2760(85)90141-9. [PubMed: 4041477]

57. Assmann G, Cullen P, Erbey J, Ramey DR, Kannenberg F, Schulte H. Nutr Metab Cardiovas. 2006; 16:13-21. http://dx.doi.org/10.1016/j.numecd.2005.04.001.

58. Miettinen TA, Railo M, Lepantalo M, Gylling H. J Am Coll Cardiol. 2005; 45:1794-1801. http:// dx.doi.org/10.1016/j.jacc.2005.02.063. [PubMed: 15936608]

59. Miettinen TA. Eur J Clin Invest. 1980; 10:27-35. http://dx.doi.org/10.1111/j. 1365-2362.1980.tb00006.x. [PubMed: 6768564]

60. Katayama S, Satoh T, Yagi T, Hirose N, Kurita Y, Anzai T, Asakura Y, Yoshikawa T, Mitamura H, Ogawa S. Internal Med. 2003; 42:591-594. http://dx.doi.org/10.2169/internalmedicine.42.591. [PubMed: 12879952]

61. Wilund KR, Yu L, Xu F, Vega GL, Grundy SM, Cohen JC, Hobbs HH. Arterioscl Thromb Vas. 2004; 24:2326-2332. http://dx.doi.org/10.1161/01.ATV.0000149140.00499.92.

62. Kurano M, Iso-O N, Hara M, Noiri E, Koike K, Kadowaki T, Tsukamoto K. J Atheroscler Thromb. 2011; 18:373-383. http://dx.doi.org/10.5551/jat.6999. [PubMed: 21266789]

63. Othman RA, Moghadasian MH. Nutr Rev. 2011; 69:371-382. http://dx.doi.org/10.1111/j. 1753-4887.2011.00399.x. [PubMed: 21729090]

64. Myrie SB, Mymin D, Triggs-Raine B, Jones PJ. Am J Clin Nutr. 2012; 95:837-844. http:// dx.doi.org/10.3945/ajcn.111.028985. [PubMed: 22378727]

65. Yoshida A, Naito M, Miyazaki K. J Atheroscler Thromb. 2000; 7:33-38. http://dx.doi.org/10.5551/ jat1994.7.33. [PubMed: 11425042]

66. Melenotte C, Carrié A, Serratrice J, Weiller PJ. J Clin Lipid. 2014; 8:451-454. http://dx.doi.org/ 10.1016/j.jacl.2014.06.003.

67. Merkens, LS.; Myrie, SB.; Steiner, RD.; Mymin, D. Gene Reviews(R). Pagon, RA.; Adam, MP.; Ardinger, HH.; Bird, TD.; Dolan, CR.; Fong, CT.; Smith, RJH.; Stephens, K., editors. Seattle (WA): 2013.

68. Nunez Rodriguez FJ, Garcia Barcina MJ, Martinez de Lizarduy I, Fernandez Ramos C, Sanchez Gonzalez E. An Pediatr (Barc). 2014

69. Baila-Rueda L, Mateo-Gallego R, Lamiquiz-Moneo I, Cenarro A, Civeira F. J Clin Lipidol. 2014; 8:520-524. http://dx.doi.org/10.1016/j.jacl.2014.05.004. [PubMed: 25234565]

70. Kaya Z, Niu DM, Yorulmaz A, Tekin A, Gursel T. Pediatr Blood Cancer. 2014; 61:1457-1459. http://dx.doi.org/10.1002/pbc.24934. [PubMed: 24623560]

71. Rios J, Stein E, Shendure J, Hobbs HH, Cohen JC. Hum Mol Genet. 2010; 19:4313-4318. http:// dx.doi.org/10.1093/hmg/ddq352. [PubMed: 20719861] 
72. Chong JX, Ouwenga R, Anderson RL, Waggoner DJ, Ober C. Am J Human Genet. 2012; 91 :608620. http://dx.doi.org/10.1016/j.ajhg.2012.08.007. [PubMed: 22981120]

73. Sanders DJ, Minter HJ, Howes D, Hepburn PA. Food Chem Toxicol. 2000; 38:485-491. http:// dx.doi.org/10.1016/S0278-6915(00)00021-1. [PubMed: 10828500]

74. Newill H, Loske R, Wagner J, Johannes C, Lorenz RL, Lehmann L. Mol Nutr Food Res. 2007; 51:888-898. http://dx.doi.org/10.1002/mnfr.200700025. [PubMed: 17579897]

75. Ju YH, Clausen LM, Allred KF, Almada AL, Helferich WG. J Nutr. 2004; 134:1145-1151. [PubMed: 15113961]

76. Dieter MZ, Maher JM, Cheng X, Klaassen CD. Compar Biochem Physiol. 2004; 139:209-218. http://dx.doi.org/10.1016/j.cbpc.2004.07.010.

77. Solca C, Tint GS, Patel SB. J Lipid Res. 2013; 54:397-409. http://dx.doi.org/10.1194/jlr.M031476. [PubMed: 23180829]

78. Mannucci L, Guardamagna O, Bertucci P, Pisciotta L, Liberatoscioli L, Bertolini S, Irace C, Gnasso A, Federici G, Cortese C. Eur J Clin Invest. 2007; 37:997-1000. http://dx.doi.org/ 10.1111/j.1365-2362.2007.01880.x. [PubMed: 17976197]

79. Tsubakio-Yamamoto K, Nishida M, Nakagawa-Toyama Y, Masuda D, Ohama T, Yamashita S. J Atheroscler Thromb. 2010; 17:891-900. http://dx.doi.org/10.5551/jat.4614. [PubMed: 20543520]

80. Parsons HG, Jamal R, Baylis B, Dias VC, Roncari D. Clin Invest Med. 1995; 18:389-400. [PubMed: 8529322]

81. Cobb MM, Salen G, Tint GS. J Am Coll Nutr. 1997; 16:605-613. http://dx.doi.org/10.1016/ S0026-0495(96)90130-4. [PubMed: 9430090]

82. Nguyen LB, Cobb M, Shefer S, Salen G, Ness GC, Tint GS. J Lipid Res. 1991; 32:1941-1948. [PubMed: 1816322]

83. Cobb MM, Salen G, Tint GS, Greenspan J, Nguyen LB. Metabolism. 1996; 45:673-679. [PubMed: 8637439]

84. Hidaka H, Kojima H, Kawabata T, Nakamura T, Konaka K, Kashiwagi A, Kikkawa R, Shigeta Y. J Atheroscler Thromb. 1995; 2:60-65. http://dx.doi.org/10.5551/jat1994.2.60. [PubMed: 9225210]

85. Wang J, Joy T, Mymin D, Frohlich J, Hegele RA. J Lipid Res. 2004; 45:2361-2367. http:// dx.doi.org/10.1194/jlr.M400310-JLR200. [PubMed: 15375183]

86. Niu DM, Chong KW, Hsu JH, Wu TJ, Yu HC, Huang CH, Lo MY, Kwok CF, Kratz LE, Ho LT. J Inherit Metab Dis. 2010; 33:437-443. http://dx.doi.org/10.1007/s10545-010-9126-2. [PubMed: 20521169]

87. Hidaka H, Nakamura T, Aoki T, Kojima H, Nakajima Y, Kosugi K, Hatanaka I, Harada M, Kobayashi M, Tamura A, et al. J Lipid Res. 1990; 31:881-888. [PubMed: 2380636]

88. Kusters DM, Vissers MN, Wiegman A, Kastelein JJ, Hutten BA. Expert Opin Pharmacother. 2010; 11:739-753. http://dx.doi.org/10.1517/14656561003592169. [PubMed: 20210683]

89. Buchwald H, Gebhard RL. Am J Physiol. 1964; 207:567-572. [PubMed: 14220024]

90. Nguyen LB, Shefer S, Salen G, Horak I, Tint GS, McNamara DJ. Metabolism. 1988; 37:346-351. http://dx.doi.org/10.1016/0026-0495(88)90134-5. [PubMed: 3357417]

91. Nguyen L, Salen G, Shefer S, Shore V, Tint GS, Ness GC. Arteriosclerosis. 1990; 10:289-297. http://dx.doi.org/10.1161/01.ATV.10.2.289. [PubMed: 2317163]

92. Salen G, Starc T, Sisk CM, Patel SB. Gastroenterology. 2006; 130:1853-1857. http://dx.doi.org/ 10.1053/j.gastro.2006.02.027. [PubMed: 16697747]

93. Sudhop T, Lütjohann D, Von Bergmann K. Pharmacol Therapeut. 2005; 105:333-341. http:// dx.doi.org/10.1016/j.pharmthera.2004.10.011.

94. Lutjohann D, von Bergmann K, Sirah W, Macdonell G, Johnson-Levonas AO, Shah A, Lin J, Sapre A, Musliner T. Int J Clin Pract. 2008; 62:1499-1510. http://dx.doi.org/10.1111/j. 1742-1241.2008.01841.x. [PubMed: 18822021]

95. Salen G, von Bergmann K, Lutjohann D, Kwiterovich P, Kane J, Patel SB, Musliner T, Stein P, Musser B. Circulation. 2004; 109:966-971. http://dx.doi.org/10.1161/01.CIR. 0000116766.31036.03. [PubMed: 14769702] 
96. Musliner T, Cselovszky D, Sirah W, McCrary Sisk C, Sapre A, Salen G, Lütjohann D, von Bergmann K. Int J Clin Pract. 2008; 62:995-1000. http://dx.doi.org/10.1111/j. 1742-1241.2008.01786.x. [PubMed: 18484971]

97. Miettinen TA, Klett EL, Gylling H, Isoniemi H, Patel SB. Gastroenterology. 2006; 130:542-547. http://dx.doi.org/10.1053/j.gastro.2005.10.022. [PubMed: 16472606]

98. Park JH, Chung IH, Kim DH, Choi MH, Garg A, Yoo EG. J Clin Endocrin Metab. 2014; 99:15121518. http://dx.doi.org/10.1210/jc.2013-3274. 


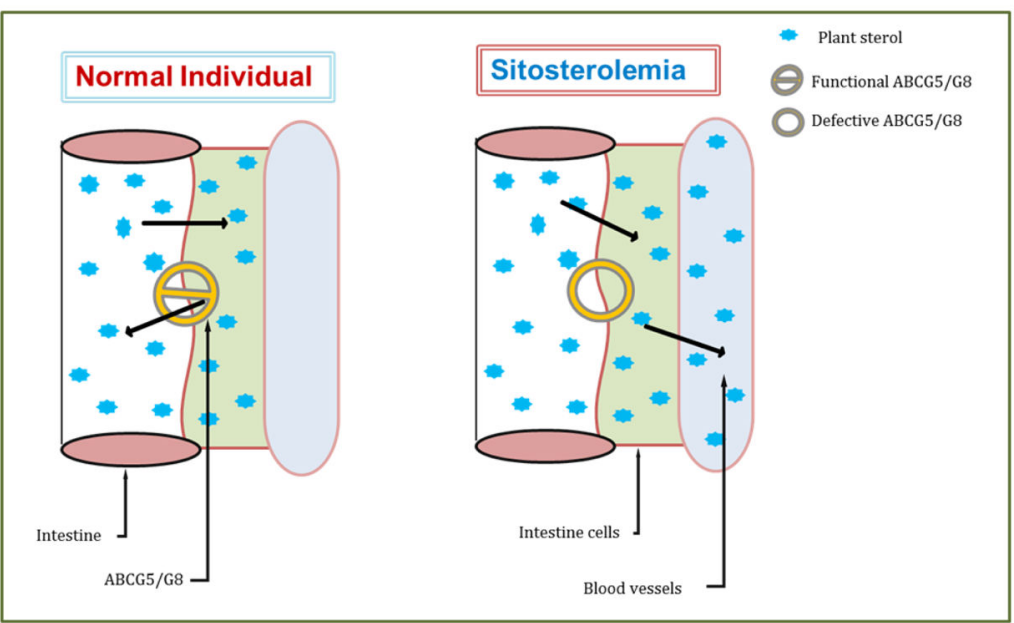

Figure 1.

The mutation in ABCG5/8 in the diseased condition causes plant sterols to be transported from the intestinal lumen back into the blood vessels. Abbreviations: ABCG5/8, adenosine triphosphate (ATP)-binding cassette G5/G8. 


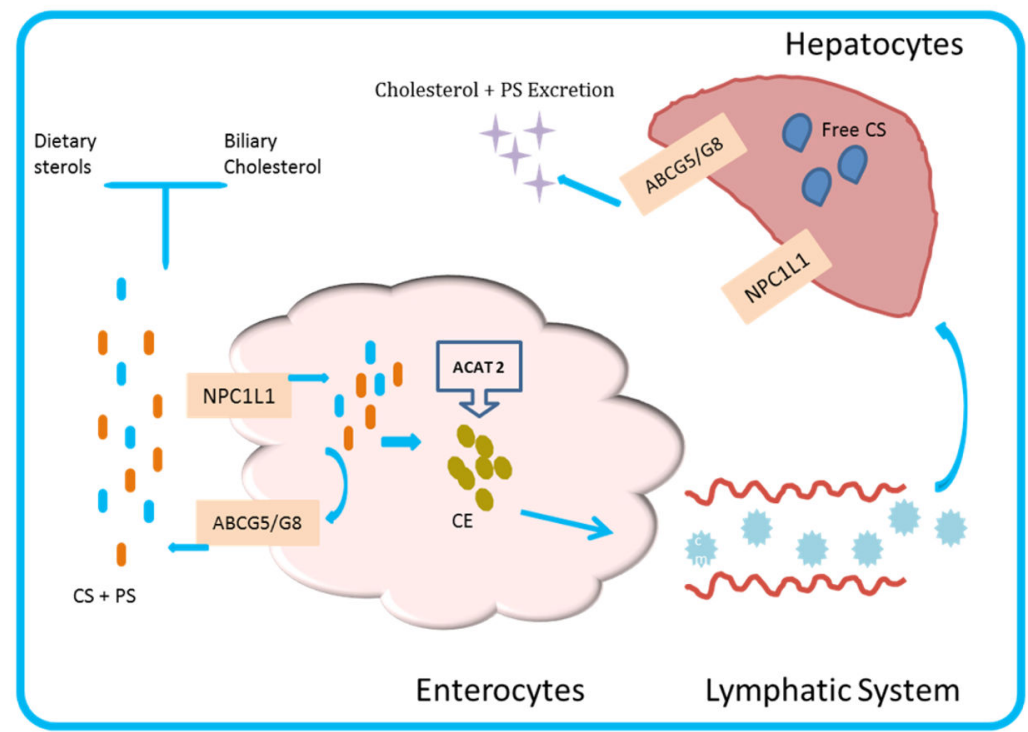

Figure 2.

Cholesterol and plant sterols biliary and intestinal absorption. The adenosine triphosphate (ATP)- binding cassette ABCG5/8 transporter function is to excrete free cholesterol from the intestinal lumen. Presence of NPC1L1 in the apical membrane of enterocytes and hepatocytes does facilitate intestinal and biliary cholesterol absorption, and uptake of PS from the gut lumen. ABCG5 and ABCG8 that are expressed in hepatocytes also promote the biliary excretion of cholesterol and PS. Abbreviations: ACAT 2, Acylcholesterol acyl transferase; NPC1L1, Niemann-Pick C1-Like 1; ABCG5/8, Adenosine triphosphate (ATP)binding cassette G5/G8; Chylomicrons(CM); CS, cholesterol; CE, cholesterol ester. 


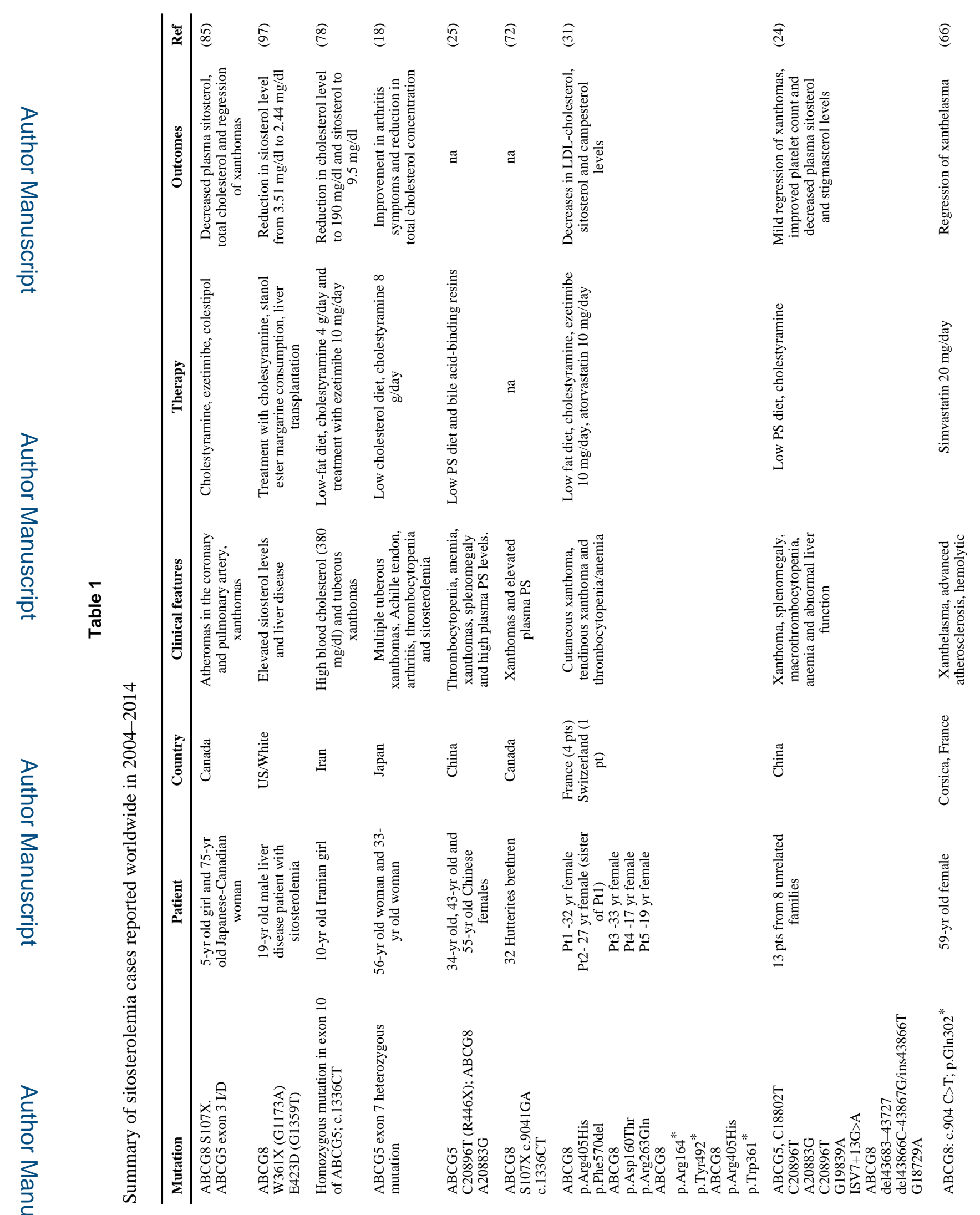

J AOAC Int. Author manuscript; available in PMC 2015 July 24. 
Ajagbe et al.

Page 16

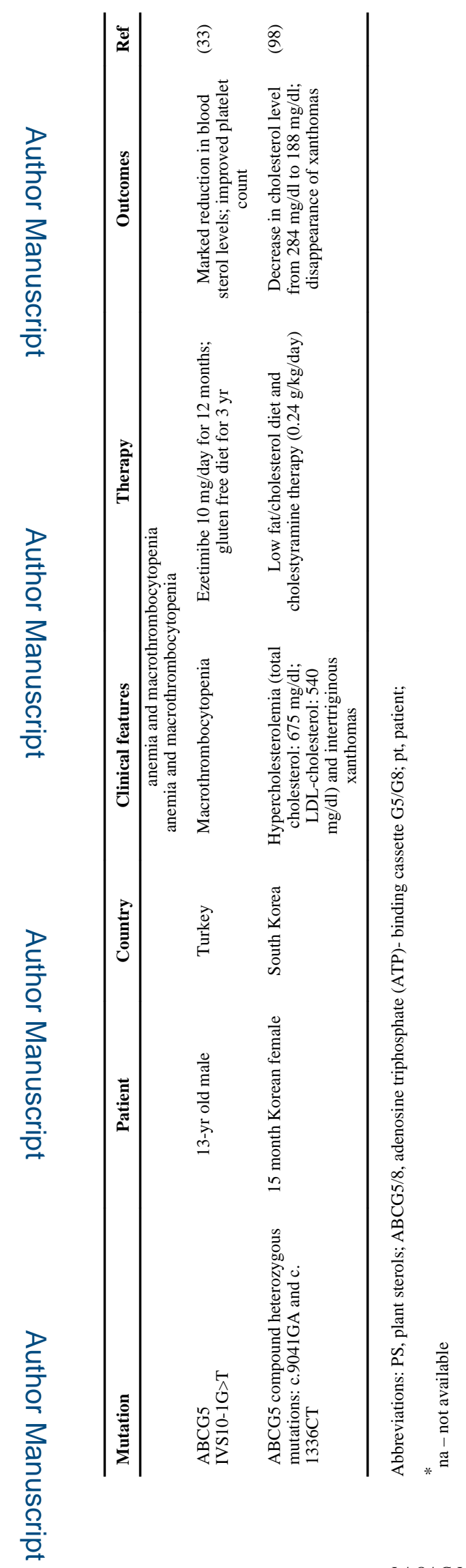

J AOAC Int. Author manuscript; available in PMC 2015 July 24. 